\title{
National Assembly Expenditure and Economic Growth in Nigeria: An Empirical Analysis
}

\author{
Ifere, Eugene Okoi ${ }^{1,}$, Okoi, Okoiarikpo Benjamin ${ }^{1}$ \& Eko, Eko Omini ${ }^{1}$ \\ ${ }^{1}$ Department of Economics, University of Calabar, Calabar, Nigeria \\ *Corresponding author: Department of Economics, University of Calabar, Calabar, Nigeria. \\ Tel: 234-805-405-7717 E-mail: eugeoifere@yahoo.com
}

Received: August 16, 2013 Accepted: February 26, 2014 Published: April 30, 2014

doi:10.5296/rae.v6i2.5560 URL: http://dx.doi.org/10.5296/rae.v6i2.5560

\begin{abstract}
The persistent public outcry in recent times over the perceived unnecessarily large expenditure on the Nigerian national assembly, and the question of the extent of their contribution to the overall growth of the nation is worrisome. This study is set out to investigate, the relationship between expenditure on the National Assembly and the level of economic growth in Nigeria. The methodology for achieving the objective of this research is the ordinary least square (OLS) estimation technique. The data set to support this objective is the time series data from 1999 to 2012. Our findings revealed that expenditure on the national assembly had a significant impact on level of economic growth (proxied by GDP), while a significant relationship exist between the contribution of National Assembly (proxied by number of bills passed) on economic growth. This calls for passage of more meaningful bills to drive the Nigerian economy higher.
\end{abstract}

Keywords: national assembly, expenditure, economic growth

Jel Classification: H5, H53 


\section{Introduction}

Government expenditure remains one of the most important instruments for influencing the level of economic activity in a country. However, prior to the occurrence of the great depression of the 1920's government played a very minimal role in the direction of economic activities in national economies. The great depression and the associated advent of Keynesian economics raised awareness of the importance of government expenditure as an instrument for the stabilization of the economy. This awareness ushered in a new era where there was a deliberate attempt by the government to influence economic activities through its expenditure.

In Nigeria, government expenditure may be divided into two: capital and recurrent expenditure (Saheed, 2012). The capital expenditure includes all expenditure on the development of assets such as the building of roads, hospitals, air and sea ports, electrical infrastructure, as well as educational infrastructure (Modebe et al., 2012; Aladejare, 2013). Recurrent expenditure on the other hand, includes items such as administrative expenditure, expenditure on the provision of economic, social and community services, as well as expenditure on transfer payments (CBN, 2012; Aladejare, 2013). With the advent of democracy in 1999, a significant part of the expenditure on administration has been accounted for by expenditure on the national assembly.

The implications of government expenditure for the Nigerian economy can be seen in terms of the sluggish rate of growth which was experienced in the 1980s, due to the contraction in the expenditure of the government as a result of declining revenues from the sale of crude oil caused by the rapid decline in the price of oil within the period. Government expenditure can also have a negative impact on the economy when it leads to the persistence of inflationary pressures. However, there is a general agreement among economists that government spending will become burdensome at some point, either because such expenditure becomes burdensome or because it is misallocated (Mitchell, 2005).

The importance of the expenditure on the national assembly derives from the role of the legislature in the creation of an enabling and business friendly environment for the growth of economic activities through the promulgation, review and amendment of laws, the evaluation and approval of national budgets, as well as their oversight functions which has to do with the power of the national assembly to review, monitor and supervise agencies, programmes, activities and policy implementation of the executive arm of government (Ndoma-Egba, 2012; Okere, 2012). In this regard, the activities of the national assembly may be seen as having an indirect impact on the economy.

In Nigeria, the recent activities of the national assembly towards accelerating the countries growth include; the passing into law of the power sector reform act which is meant to provide a solution to the country's power problem, seen as major constraints to the growth of economic activities in the country, the petroleum industry bill, the freedom of information bill, the anti-terrorism bill and the minimum wage bill, all of which is anticipated to have, a huge impact on the level of economic activity in the country. 
Legislative expenditures generally have an indirect effect on the level of economic activities in a country. Thus, while there is a clear picture as to the relative importance of the expenditure on items such as the provision of the necessary infrastructure, education, health and the military, and the impact of government expenditure taken as a whole, the expenditure on the legislature, its relative size, as well as the growth implications of such expenditure is still unclear. This ambiguity is the source of the current controversy surrounding the expenditure on the legislature, with people differing in their views on the importance of the huge sums of money spent on the maintenance of "two legislative houses" and its impact on the economy. According to Agomuo (2012), since 1999 critics have argued that the contribution of the federal legislative houses to the welfare of the masses pales into insignificance when compared with the expenditure required to maintain their excesses. Agomuo (2012) further pointed out that as at October 2012 each member of the House of Representatives was earning an estimated twenty seven million naira per quarter as allowances. Proshare (2013) observed that since June 2007 to date, the house of representatives has not passed ten bills because most of their time is spent sharing money. They further argued that law makers' mentality of grabbing everything in sight is impacting on others around the economy. Items that money is appropriated for, they argued, are suffering because they were in the first place not in the priority list of legislators.

In view of the above, an attempt is made in this paper to study the impact of the expenditure on the maintenance of the two legislative houses of the national assembly on the economic growth of Nigeria. The conclusions of this study will thus provide the platform for the future assessment of the activities of the national assembly and impact on the economy. The remainder of the paper proceeds as follows: Section 2 presents a brief review of literature on the subject matter; the methodology of the study is presented in section 3, while the empirical results and discussion of findings is presented in section 4. Finally, section 5 contains the summary and conclusion.

\section{Review of Related Literature and Theoretical Issues}

A lot of empirical work has been done on the growth impact of government expenditure, especially with regards to the Nigerian economy. While the focus of most of such studies is on the impact of government expenditure as a whole on the level of output in the economy, others are based on the examination of the impact of the individual components of government expenditure on individual target sectors, thus giving a clearer picture. Some of these empirical findings are briefly presented as follows:

In investigating the impact of public expenditure on economic growth in Nigeria, Nworji, et al (2012) found that capital and recurrent expenditure on economic services had insignificant negative effect on economic growth during the study period. Also, capital expenditure on transfers had insignificant positive effect on growth. But capital and recurrent expenditures on social and community services and recurrent expenditure on transfers had significant positive effect on economic growth. The results of Samuel and Kabir (2011) also yielded a significant relationship between the total capital expenditure and economic growth in Nigeria. 
Saheed (2012) examined the impact of government capital expenditure on exchange rate in Nigeria, using disaggregated approach. The findings of the study indicated that the government's capital expenditure, especially government spending on social and community services has a statistically significant impact on exchange rate in Nigeria, while capital expenditures on administration, economic services and transfer are not statistically significant in respect to their impact on exchange rate. In studying the effect of the composition of public expenditure on growth in Nigeria using the vector error correction approach (VEC), Eregha, Sede, and Onotaniyohwo (2012) found that the expenditure on transfers had a significant but negative impact on growth while the expenditure on economic and social-community services had a significant and positive impact on growth.

Odior (2011) used an integrated sequential dynamic computable general equilibrium (CGE) model in his study of the impact of increase in government expenditure on education, and its impact on economic growth in Nigeria. The results of his model, which was calibrated using the 2004 social accounting matrix (SAM) data of the Nigerian economy, indicated that the re-allocation of government expenditure to education sector was significant in explaining economic growth in Nigeria. He therefore recommended that the Nigerian government should be able to move resources from other sectors to provide quality education for her citizens. This type of expenditure he argues, not only has a large impact on poverty per Naira spent, but also produces greatest growth in human productivity.

Sevitenyi (2012) studied the direction of causality between government expenditure and economic growth in Nigeria using annual data between 1961 and 2009, using co-integration tests and the Toda-Yamamoto Granger Causality test. His results from the Toda-Yamamoto causality test indicated that there is a unidirectional causality running from total government expenditure to economic growth. At the disaggregate level, his results revealed that all the variables except total recurrent expenditure cause economic growth, implying that government expenditure promotes growth in Nigeria. He thus concluded that his findings do not support the existence of Wagner's law both at the aggregate and the disaggregate levels in Nigeria.

Ike and Kalu (2011) used the neoclassical growth framework and Granger causality test in examining the level of impact and direction of causality respectively between government expenditure and economic growth in Nigeria. The growth model was decomposed into long run static equation and short run dynamic error correction model during the analyses. Their results indicated that public expenditure is statistically significant in promoting economic growth in Nigeria. The results of the causality test between recurrent expenditure and gross domestic product revealed a unidirectional case; with growth running from the latter to the former. Also, the causal relationship between capital expenditure and gross domestic product was observed to be unidirectional; with growth running from gross domestic product to capital expenditure. However, the result also showed a bi-directional relationship between recurrent and capital expenditure.

In a related study, Chiawa et al (2012) studied the relationship between government expenditure and economic growth in Nigeria, using co-integration and causality analysis. The 
study employed the Augmented Dickey-Fuller (ADF) unit root test, Kwiatkowski, Philips, Schmidt and Shin (KPSS) test, Johansen based co-integration and Granger causality test. The results of the Johansen co-integration tests indicated three long-run relationships between government expenditure and economic growth, while the test for causality revealed that economic growth granger-caused government expenditure. Their empirical results also indicated that there exist two unidirectional causality running from GDP to TCE and GDP to TRE which they argue, supports the Wagner's Law, that government expenditure affects economic growth. Their regression results indicated that the coefficients of TCE, TRE, TDE and THE have positive and statistically significant effect on economic growth. The results of the Error Correction Model (ECM) had negative signs and the Error Correction term (EC) indicated that there exists long run relationship between economic growth and Government expenditure. They concluded that government expenditure causes economic growth.

The results of the studies which have so far been presented generally indicate a significant relationship between government expenditure and economic growth in Nigeria. However, as it was earlier observed, the results of other studies indicate that this is not the case. These studies include those of Nurudeen and Usman (2010) who examined the impact of the various components of government expenditure on economic growth in Nigeria. Their results indicated that government total capital expenditure (TCAP), total recurrent expenditures (TREC), and government expenditure on education (EDU) have a negative effect on economic growth. However, their results revealed that rising government expenditure on transport and communication (TRACO), and health (HEA) results to an increase in economic growth.

Loto (2011) investigated the growth effect of government expenditure on economic growth in Nigeria over the period of 1980 and 2008, with a particular focus on sectoral expenditures. His study was based on the use of five key sectors; security, health, education, transportation and communication and agriculture. His results indicated that in the short-run, expenditure on agriculture is negatively related to economic growth. The impact of the expenditure on the educational sector was also observed to be negative and not significant. The impact of expenditure on health was found to be positively related to economic growth. Finally his resulted showed that while the expenditure on national security transportation and communication was positively related to economic growth, their impact was not statistically significant.

Olopade and Olopade (2010) attempted to determine the growth and development enhancing components of government expenditure. Their results indicated that there is no significant relationship between most of the components expenditure, economic growth and development. Modebe, et al. (2012) found that while recurrent government expenditure had positive and non-significant impact on economic growth, capital expenditure had negative and non-significant impact on economic growth. They therefore conclude that their results echo's the need for increase and encouragement of private sector investment.

Joseph (2012) employed the ordinary least square technique in his study of the relationship between public expenditure and industrial sector productivity in Nigeria. His model was 
based on the use of the index of industrial production as a proxy for industrial productivity, and total government expenditure, government expenditure on administration, government expenditure on economic services, and government expenditure on social and community services and government expenditure on transfer as proxies for government expenditure. His results indicated that both government expenditure on administration and government expenditure on economic services have negative impact on industrial productivity. In a similar vein, Ademola (2012) found that a significant relationship exists between government expenditure in the manufacturing sector and economic growth in Nigeria

A possible explanation for the observed negative relationship between government expenditure and some of its targets can be found in the results of Onuorah and Appah (2012) who examine the relationship between accountability and public sector financial management in Nigeria. Their empirical findings indicated that the level of accountability is very poor because the attributes of accessibility, comprehensiveness, relevance, quality, reliability and timely disclosure of economic, social and political information about government activities are completely non available or partially available for the citizens to assess the performance of public officers mostly the political office holders.

From the literature reviewed so far, it may be observed that while a lot of research has been carried out on the impact of government expenditure on economic growth in Nigeria, no attempt has so far been made to study the growth impact of the expenditure on the national assembly. This is understandable in view of the fact that the relationship between legislative expenditures and economic growth is an indirect one. Legislative expenditures essentially involve all expenditure on the maintenance of the different components of the legislature whose activities have an indirect impact on the level of productive activities in an economy. It is thus difficult to establish a direct link between the two variables. However, in this study an attempt is made to establish a link between, the efficiency of legislative expenditures and economic growth in Nigeria.

On the theoretical front, several theories may be used to provide an insight, and establish the need for, and the growth impact of government expenditure. Some of these theories are briefly presented as follows;

\subsection{Wagner's law of expanding state expenditure}

According to Wagner's law, as the per-capita incomes, growth, urbanization and increased enlightenment on the part of the electorate increase, so will the relative share of public sector in national output. An expansion of state expenditures will come about with respect to the administrative and protective functions of the state. These increases he argued are the result of the inevitable centralization of economic functions and increasing complexities in legal relationships. According to him, public expenditure must increase as a result of the need to increase economic development in cases where there is evidence of market failure (Nwezeaku, 2010).

\subsection{The critical-limit hypothesis}

According to this hypothesis, inflation will occur whenever the share of the government 
sector activity exceeds 25 percent of the total economic activity of the economy and this would be so even when a country is operating under a balanced budget. Thus, when the aggregate economic activity of the public sector exceeds the critical limit of 25 percent, income earners would be affected by reduced incentives owing to the apparent high tax incidence resulting in decreased productivity and reduced supply. The net effect of the maladjustment between demand and supply in such a situation would breed inflationary spirals in the economy (Nwezeaku, 2010).

\section{Overview of the Nigerian National Assembly since the beginning of the $4^{\text {th }}$ Republic}

The fourth republic began with the handover of power by the then military administration headed by General Abdul Salami Abubakar to the democratically elected government of Chief Olusegun Obasenjo in 1999. The national assembly which came into being on the $3^{\text {rd }}$ of June was a bicameral legislature comprised of a house of representatives made up of 360 seats - with seats allotted by relative population, and the Senate, made up of 109 seats - three per state and one for the Federal Capital Territory (Benjamin, 2011; Lewis, 2011; Nwanolue and Ojukwu, 2012).

The national assembly is charged with the responsibility of making laws, the examination and approval of national budgets, as well as other oversight functions. The legislature is required to sit at least 188 days a year. The rights and the obligations of the National Assembly have been enhanced over preceding governments (Lewis, 2011).

With regards to the aforementioned activities Fred-Adegbulugbe (2011) observes that as at 2011, the Nigerian National Assembly processed a total of 206 bills into Acts since its inauguration in 1999. A total of 556 bills (220 Senate and 336 House of Representatives) were passed by the National Assembly between 1999 and 2009. Between 1999 and 2011, 206 were forwarded for presidential assent of which 176 have been signed into laws, while 32 are still awaiting presidential assent. A brief summary of the activities of the National Assembly between 2003 and 2007 is presented in the following tables:

Table 1. Bills progression in the House of Representatives 2003-2007

\begin{tabular}{lcc}
\hline & Total number & Percentage** \\
\hline Bills presented & 333 & \\
Executive & 146 & $44 \%$ \\
Private members & 169 & $51 \%$ \\
Bills passed & $141^{*}$ & \\
Executive & 90 & $64 \%$ \\
Private members & 51 & $36 \%$ \\
\hline
\end{tabular}

Source: The Law makers: Federal Republic of Nigeria 2007-2011, Abuja: Anyanwu (as cited in Lewis, 2011).

\section{Note:}

* Bills not necessarily presented in the same year as passage.

**Bills from Senate to House not included. 
Table 2. Summary of legislative activities in the Senate between June1999 and August 2010

\begin{tabular}{lcccccccc}
\hline Title & $2003-$ & $2004-$ & $2005-$ & $2006-$ & $2007-$ & $2008-2009-$ Total \\
& 2004 & 2005 & 2006 & 2007 & 2008 & 2009 & 2010 & \\
\hline Bills Scheduled & 89 & 152 & 168 & 69 & 72 & 72 & 83 & 705 \\
Bills Presented & 87 & 119 & 168 & 69 & 65 & 67 & 54 & 629 \\
Bills not presented & 2 & 5 & - & - & - & - & - & 7 \\
Bills read the first time & 44 & 54 & 98 & 39 & 34 & 45 & 33 & 347 \\
Bills not presented & - & 5 & - & - & - & - & - & 5 \\
Bills read the second time & 42 & 55 & 34 & 7 & 5 & 8 & 12 & 163 \\
and referred to committees & & & & & & & & \\
Bills passed & 27 & 32 & 18 & 55 & 44 & 36 & 13 & 450 \\
Bills considered & 94 & 152 & 174 & 69 & 70 & 130 & 15 & 704 \\
Bills neglected & - & 3 & 5 & - & - & 4 & 2 & 14 \\
Bills withdrawn & - & 2 & 1 & 4 & 3 & 2 & 1 & 13 \\
Executive bills passed & 23 & 21 & 12 & 27 & 7 & 4 & 3 & 97 \\
Members bills passed & 4 & 11 & 6 & 28 & 23 & 12 & 6 & 90 \\
Reports presented & 13 & 19 & 18 & 12 & 16 & 23 & 18 & 238 \\
Reports laid & 4 & 10 & 15 & 7 & 8 & 10 & 11 & 65 \\
Reports considered & 9 & 9 & 3 & 3 & 9 & 8 & 12 & 53 \\
Motions presented & 61 & 34 & 27 & 31 & 10 & 25 & 31 & 219 \\
Motions referred to & 4 & 6 & 3 & 1 & 2 & 4 & 3 & 23 \\
Committees & & & & & & & & \\
Motion considered & 57 & 28 & 24 & 30 & 25 & 31 & 32 & 227 \\
\hline
\end{tabular}

Source: Statistical Bulletin on Nigerian Democracy 2011 in Nwanolue and Ojukwu (2012).

From table 1, it can be seen that while three hundred and thirty three bills were presented for passage into law in the House of Assembly between 2003 and 2007, only one hundred and forty six of such bills were actually passed into law by the house. On the other hand, table 2 contains a summary of the activities of the Senate between 1999 and 2010. From the table, it can be seen that while six hundred and twenty nine bills were presented before the Senate within the period under consideration, only four hundred and fifty of such bills were passed into law, indicating a relative better performance by the senate when compared to the House of Representatives.

\section{Methodology}

This paper uses the Ordinary Least Squares method of estimation. The choice of this method of estimation is based on its property of being the best linear unbiased (BLUE) estimator among the estimators of the parameters of a regression model. The model thus estimated will be validated on the basis of the economic-apriori criteria, the statistical criteria, which will involve the use of the $t$-statistic to test the significance of the individual explanatory variable, the F-statistic which will be used to test the overall significance of the estimated model, and the coefficient of determination $\left(\mathrm{R}^{2}\right)$ and its adjusted value which will be used to determine 
the explanatory power of each of our models. Finally, the econometric criteria will be used to test for the presence of autocorrelation in the estimated model.

The data used in this paper are derived from the annual statistical bulletin of the central bank of Nigeria. the gross domestic product (GDP) is used as the proxy for the level of economic growth, while the total annual number of bills passed by the national assembly is used as a proxy to measure the contribution of the national assembly to the country`s economic growth.

\section{The Model}

The model used in this study is based on Wagner's law of increasing state activities. The model is presented below:

$$
G D P=f(N A T E X P, \mathrm{TNBL}, U)
$$

Where

$\mathrm{GDP}=$ gross domestic product (a proxy for economic growth)

NATEXP $=$ expenditure on the national assembly

$\mathrm{TNBL}=$ total number of bills passed by the national assembly (a proxy to measure the performance and contributions of the national assembly

$\mathrm{U}=$ stochastic error term

The above model is econometrically expressed as follows:

$$
G D P=\beta_{0}+\beta_{1} N A T E X P+\beta_{2} \mathrm{TNBL}+U
$$

Where

$$
\beta_{0}>0, \beta_{1}>0 \text { and } \beta_{2}>0
$$

\section{Empirical Results}

The results derived from the estimation of the earlier specified model are presented in table 3 bellow:

Table 3. Regression results

\begin{tabular}{lccc}
\hline Variable & $\mathrm{C}$ & NATEXP & TNBL \\
\hline Coefficient & 327264.3 & 2.994316 & 3650.690 \\
Standard Error & 30522.69 & 0.261500 & 1145.713 \\
t-statistic & $10.72200^{*}$ & $11.45056^{*}$ & $3.186391^{*}$ \\
$\mathrm{R}^{2}$ & & 0.922959 & \\
Adjusted $\mathrm{R}^{2}$ & & 0.908951 & \\
F - Statistic & & $65.89029^{*}$ & \\
Durbin - Watson Statistic & & 1.520076 & \\
\hline
\end{tabular}

Source: Authors computation 
Note:

- $\mathrm{t}^{*}=2.201(5 \%$ Level of significance).

- $\mathrm{F}^{*}=3.98$ (5\% Level of significance).

- $\mathrm{D} 1=0.95$ and $\mathrm{Du}=1.54$

- *Significant at the $5 \%$ level

The coefficient of the intercept term in table 3 indicate that the gross domestic product of Nigeria will be 327264.3 irrespective of the amount of expenditure on the national assembly or number of bills passed into law by the two legislative houses. The intercept term is also significant at the $5 \%$ level of significance.

The estimated coefficient of the expenditure on the national assembly indicates a theoretically correct positive relationship between the variable and the gross domestic product, implying that a one Naira increase (decrease) in the expenditure on the national assembly will be lead to an increase (decrease) in the GDP of the country by 2.994316 percent. The expenditure on the national assembly is also statistically significant at the five percent level of significance.

The total number of bills passed into law by the national assembly is also statistically significant at the five percent level of significance, while its estimated coefficient also indicates a positive relationship between it and the gross domestic product which is in line with the theoretical expectation, implying that a one percent increase (decrease) in the number of bills passed by the national assembly would lead to an increase (decrease) in the country`s GDP by 3650.690 percent.

The coefficient of determination for the estimated model indicates that 92.2959 percent of the variation in the gross domestic product is explained by the model, while the adjusted coefficient of determination indicates that 90.8951 percent of the variation in the gross domestic product is explained by changes in the variables used in the model. On the basis of this, we may conclude that the estimated model has a good fit.

The calculated F- statistic indicates that the model as a whole is statistically significant, while the computed Durbin - Watson statistic which falls within the inconclusive region indicates neither the presence nor absence of autocorrelation in the estimated model.

\section{Conclusion and Policy Implications}

The Nigerian national assembly is a bicameral legislative body charged with the responsibility of making laws, and performing a number of well-defined oversight functions so as to promote the growth and development of the country. Thus, the expenditure on the legislative houses may be seen as a form of investment the merit of which will usually be assessed by the evaluation of the outcome of such investment. In view of this and in consideration of the varying views on the size of such expenditure in Nigeria, this study was carried out in order to ascertain the exact impact of the expenditure on the two national legislative houses on the economic growth of the country. 
Our results revealed that the expenditure on the national assembly had a significant impact on the level of economic growth in the country within the period under consideration. It also revealed a significant relationship between the total number of bills passed annually into law by the legislative houses and the level of economic growth in the country. While these results are contradictory to the popular perception of the impact of the activities of the national assembly, they may be explained in terms of the significance of some of the bills which have been passed into law by the legislative houses within the period under consideration. Such activities include the bills for the deregulation of the telecommunications sector, the approval of the act empowering the Central Bank of Nigeria (CBN) to implement its bank reconsolidation exercise, the power sector reform act, the acts which brought into being the institutions such as the Economic and Financial Crimes Commission (EFCC) and the Independent Corrupt Practices Commission (ICPC), as well as other relevant pieces of legislation, all of which have contributed to the improvement of the business environment in the country and thus led to an increase in the level of investment in productive activities. The results are also in line with the findings of similar studies on the growth impacts of public expenditure for the Nigerian economy. Such findings include those of Chiawa et al. (2012), whose results indicated that government recurrent expenditure has a significant impact on the growth of the economy. Others studies of such include those carried out by Odior (2011) and Samuel and Kabir (2011) revealed a significant relationship between the different components of government expenditure and growth in the different sectors of the Nigerian economy.

Our results are however not in agreement with those of Modebe, et al. (2012) and Sevitenyi (2012) whose results indicated that the total recurrent expenditure of the government does not cause economic growth, the results of Nurudeen and Usman (2010) who found that the total recurrent expenditures (TREC), and government expenditure on education (EDU) have a negative effect on economic growth, and in particular, Joseph (2012) whose results revealed that both government expenditure on administration and government expenditure on economic services have negative impact on industrial productivity. Given that legislative expenditure constitutes a significant part of the total recurrent expenditure, such findings may be seen as indicating that the expenditure on the national assembly has an insignificant impact on economic growth in Nigeria.

In general, the observed positive relationship between the expenditure on the national assembly and its activities, and the level of economic growth in the country should not be cause for the reduction in the effort of the members of the legislative houses towards the growth of the nation. Rather, it should be seen as an incentive towards the intensification of efforts towards ensuring higher levels of efficiency, both in terms of the number of significant bills passed into law such as the petroleum industry bill in the legislative houses, as well as the efficiency of the use of existing funds, so as to further improve their contribution to the nation as a whole. This view is based on the current inadequacy in the funds available to the federal government and in line with the recent advocacy by the governor of the Central Bank of Nigeria on the need for the reduction in the size of the overall expenditure on the government which he argues is unsustainable in the long run. 


\section{References}

Ademola, I. S. (2012).Government expenditure in the manufacturing sector and economic growth in Nigeria. International Journal of Scientific and Engineering Research, 3(11).

Aladejare, S. A. (2013). Government spending and economic growth: evidence from Nigeria. MPRA Paper, 43916. Retrieved from http://mpra.ub.uni-muenchen.de/43916/

Central Bank of Nigeria. (2012). Statistical bulletin. Retrieved from http://www.cenbank.org

Chiawa, M. M., Torruam, J. T., \& Abur, C. C. (2012). Cointegration and causality analysis of government expenditure and economic growth in Nigeria. International Journal of Scientific \& Technology Research, 1(8), 165-174.

Eregha, P. B., Sede, P. I., \& Onotaniyohwo, F. O. (2012). Does the composition of public expenditure matter for growth in Nigeria: A vector error correction approach. Pakistan Journal of Social Sciences, 9(3), 125-131.

Gujarati, D. N., \& Porter, D. C. (2009). Basic Econometrics. McGraw-Hill/Irwin, New York.

Joseph, T. (2012). Effects of public expenditure on industrial sector productivity in Nigeria. Canadian, $\quad$ Social $\quad$ Science, $\quad 8(1), \quad 204-214$. http://dx.doi.org/10.3968/j.css.1923669720120801.219

Ike, N. M., \& Kalu, N. O. (2011).Increasing size of government: implication for output growth in Nigeria. Retrieved from http://ssrn.com/abstract $=1911843$

Koutsoyannis, A. (2001). Theory of Econometrics (2nd ed). Palgrave Publishers, New York.

Lewis, P. M. (2011). Nigeria country report. Center for Social Research, Democracy in Africa Unit, Universit of Cape Town, South Africa. Retrieved from http://www.cssr.uct.ac.za

Loto, M. A. (2011). Impact of government sectoral expenditure oneconomic growth. Journal of Economics and International Finance, 3(11), 646-652. Retrieved from http://www.academicjournals.org/JEIF

Modebe, N.J., Okafor, R. G., Onwumere, J.U.J., \& Ibe, I. G. (2012). Impact of recurrent and capital expenditure on Nigeria' economic growth. European Journal of Business and Management, 4(19), 66-75. Retrieved from http://www.iiste.org

Ndoma-Egba, V. (2012). Legislative oversight and public accountability. University of Nigeria, Nsuka, Enugu State, Nigeria.Retrieved from http://www.unn.edu.ng

Nurudeen, A., \& Usman, A. (2010). Government expenditure and economic growth in Nigeria (1970-2008): A disaggregated analysis. Business and Economics Journal, 4.

Nwanolue, B. O. G., \& Ojukwu, U. G. (2012). Legislative efficiency and democratic stability in the fourth republic governance and politics of Nigeria: A re-appraisal of national assembly. Kuwait Chapter of Arabian Journal of Business and Management Review, 1(9), 116-131. 
Nwezeaku, N. C. (2010). The impact of public sector financial management on the economies of sub-saharan Africa. International Research Journal of Finance and Economics, 40, 87-99. Retrieved from http://www.eurojournals.com/finance.htm

Nworji, I. D., Okwu, A. T., Obiwuru, T. C., \& Nworji, L. O. (2012). Effects of public expenditure on economic growth in Nigeria: A disaggregated time series analysis. International Journal of Management Sciences and Business Research, 1(7), 1-15.

Odior, E. S. O. (2011). Government spending on education, economic growth and long waves in a CGE micro-simulation analysis: The case of Nigeria. British Journal of Economics, Finance and Management Sciences, 1(2), 74-87.

Olopade, B.C., \& Olopade, D.O. (2010). The impact of government expenditure on economic growth and development in developing countries: Nigeria as a case study.

Onuorah, A. C., \& Appah, E. (2012). Accountability and public sector financial management in Nigeria. Arabian Journal of Business and Management Review (OMAN Chapter), 1(6), 1-17.

Saheed, Z. S. (2012). Impact of capital expenditure on exchange rate within the period of the second and fourth republic in Nigeria. Journal of Economics and Sustainable Development, 3(10), 76-82. Retrieved from http://www.iiste.org

Samuel, T. A., \& Kabir, A. K. (2011). Government expenditure in Nigeria: A sine qua non for economic growth and development. JORIND, 9(2), 155-162. Retrieved from http://www.transcampus.org

Sevitenyi, L. N. (2012). Government expenditure and economic growth in Nigeria: An empirical investigation (1961-2009). Journal of Economic Analysis, 3(1), 38-51.

Mitchell, D. J. (2005, March 15). The impact of government spending on economic growth. The Heritage Foundation. Retrieved from http://www.heritage.org

Fred-Adegbulugbe, C. (2011, May 18). Nigeria: National assembly makes 206 laws in 11 years. All Africa. Retrieved from http://allafrica.com/stories/201105180348.html

Okere, R. (2012, July 11). Tackling business challenges with legislative measures in Nigeria. The Guardian Nigeria. Retrieved from http://www.guardiannewsngr.com

Agomuo, Z. (2012, October 1). Relevance of Nigeria's national assembly. Business Day. Retrieved from http://www.businessday.com

Proshare. (2013, July 8). National assembly: The biggest democracy cost centre. Retrieved from http://www.proshareng.com

Benjamin, S. (2011, September 10). 12 years of legislative work: National assembly in retrospect. The Nigeria Standard. Retrieved from http://www.thenigerianstandard.com 


\section{Copyright Disclaimer}

Copyright reserved by the author(s).

This article is an open-access article distributed under the terms and conditions of the Creative Commons Attribution license (http://creativecommons.org/licenses/by/3.0/). 